Review

\title{
A Scoping Review of Renewable Energy, Sustainability and the Environment
}

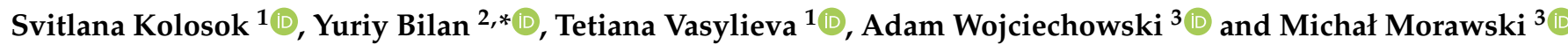 \\ 1 BiEM, Sumy State University, 40007 Sumy, Ukraine; kolosok@management.sumdu.edu.ua (S.K.); \\ tavasilyeva@fem.sumdu.edu.ua (T.V.) \\ 2 Faculty of Management, Rzeszów University of Technology, 35959 Rzeszów, Poland \\ 3 Institute of Information Technology, Lodz University of Technology, 90924 Lodz, Poland; \\ adam.wojciechowski@p.lodz.pl (A.W.); michal.morawski@p.lodz.pl (M.M.) \\ * Correspondence: y.bilan@prz.edu.pl
}

Citation: Kolosok, S.; Bilan, Y.;

Vasylieva, T.; Wojciechowski, A.;

Morawski, M. A Scoping Review of

Renewable Energy, Sustainability and the Environment. Energies 2021, 14,

4490. https://doi.org/10.3390/ en14154490

Academic Editor:

Alberto-Jesus Perea-Moreno

Received: 28 June 2021

Accepted: 22 July 2021

Published: 25 July 2021

Publisher's Note: MDPI stays neutral with regard to jurisdictional claims in published maps and institutional affiliations.

Copyright: (c) 2021 by the authors. Licensee MDPI, Basel, Switzerland. This article is an open access article distributed under the terms and conditions of the Creative Commons Attribution (CC BY) license (https:// creativecommons.org/licenses/by/ $4.0 /)$.
Abstract: The article aims to identify the latest trends in research on renewable energy, sustainability and the environment. A total of 92,873 publications from 123 Scopus sources for 2020-2021 are compared using the scoping review method. The results show that the most cited works in this sample are those by authors from the Asian region. The research of these authors focuses on the security, efficiency and reliability of separate elements in energy systems. Besides, the paper considers the problems regarding COVID disease along with the renewable energy sources, perovskite and organic solar panels, nanostructured materials and high energy density. Finally, the paper analyses applications of computer science methods in research on renewable energy, sustainability and the environment. The findings evidently show that recent advancements in computer science methods were not extensively used in the discussed research domain and give a great room for novel strategies of prognosing, simulation and processes optimisation.

Keywords: clean energy innovation; environmental sustainability; renewable energy

\section{Introduction}

Researchers have been significantly interested in renewable energy, sustainable development and environmental protection in recent years. Constant changes in energy markets to increase green energy consumption stimulate studies and publication activity globally [1,2]. Governments of all countries face ambitious challenges for the goals of 2030 and the demands to counteract climate changes $[3,4]$ and reduce greenhouse gas emissions [5,6]. The environmental component is an integral part of sustainable development, the impact of which is greatly enhanced due to the extensive use of fossil resources and insufficient environmental protection. Uncontrolled pollution of territories can lead to economic consequences and negatively impact the environment $[7,8]$, causing ecological disasters and migration of the working population $[9,10]$. At the same time, the Paris Agreement 2015 contains regulated requirements that disturb the transformation of energy balances in terms of reducing the share of coal $[11,12]$ and expanding green energy production in the energy sector [13]. Given this and considering the fluctuations of generating power based on most green energy sources [14,15], it does not seem strange to find ways to balance the growing share of renewable energy sources in conventional energy systems [16,17]. Unfortunately, the existing solutions have drawbacks.

The scientific community conducts discussions and studies of economic efficiency regarding renewable energy sources [18,19]. Given the criticism of the current approach to assessing economic efficiency, the criteria and methods for measuring it are widely discussed [20,21]. However, not all countries have been able to achieve certain efficiency targets so far. There is a gap between potential and actual energy generation from renewable energy sources [22,23] and indicators of its productivity [24,25]. A possible solution, 
in this case, will be to expand the use of green innovations, smart grids [26,27], promising energy storage technologies $[28,29]$. The accelerated consumption of renewable energy resources is stimulated in the interested communities [30]. In the real world, citizen energy communities and renewable energy communities are formed, where changes are adapted, and the green innovation diffusion processes occur [31,32]. The existing infrastructure is used, and a new one, which can cope with the load when using renewable energy [33,34], is built to support and function such communities. The deployment of microgrids and virtual power plants is among the many innovations needed to integrate renewable energy sources [35,36]. In addition, the transition to sustainable business models $[37,38]$ requires updating the requirements for flexibility, security [39,40], management of energy systems $[41,42]$. On the part of the state, such an update can be stimulated via institutions quality standards [43], environmental taxes [44,45], environmental responsibility strategies [46], security $[47,48]$ and ecological standards $[49,50]$, the requirements for industry safety indicators $[51,52]$ and the introduction of comprehensive training programs $[53,54]$. Therefore, new research topics are rapidly emerging, driven by current changes and technologies in the energy sector. It is possible to name new technologies for the production and storage of energy $[55,56]$, new requirements for the provision of basic functions in the COVID-19 pandemic [57,58]. Such topics require detailed study [59], determining the role and directions of the transition to sustainable green energy, the main factors in combating irreversible climate change, identifying drivers to ensure a green energy breakthrough, which is the purpose of this study.

This article consists of four sections. In the next section, the authors describe the research methodology and the main stages of the scoping review. The third section presents the results and issues related to the analysis of new topics and clusters, research results of institutions and leading authors in the subject area 'Renewable energy, sustainability and the environment' for 2020-2021. The conclusions complete this article.

\section{Materials and Methods}

The concept of the study was based on an adapted approach to the scoping review, considering the methodologies outlined in several works [60,61]. Given the potential and comprehensive coverage of the scientific literature on renewable energy, the authors ask the following research question: 'What are the latest trends in research in the subject area, Renewable energy, sustainability and the environment?' The scoping review in this work was performed to analyse the scientific literature from the Scopus database as of 7 April 2021, and to maximise the coverage of promising research for 2015-2021. For the general estimation of tendencies in the chosen subject area, 363,255 publications were found by All Science Journal Classification Codes (ASJC) subject area: 'Renewable energy, sustainability and the environment', among which 270,382 units were excluded (by date and type of publications). During 2020-2021, the authors selected a total of 78,126 articles and 14,747 conference papers. The final database of the study contained 92,873 publications by 302,587 authors. Figure 1 shows the general methodology of the study.

Content analysis of publications was performed using analytical applications for data visualisation of scientific publications: SciVal (scival.com, Copyright $@ 2021$ Elsevier B.V.; accessed on 7 April 2021) and VOSviewer 1.6.16 (vosviewer.com, Copyright () 2021 Centre for Science and Technology Studies, Leiden University, Leiden, The Netherlands; downloaded on 7 April 2021). Performance indicators, research of topics and topic clusters, works of authors and institutions in publications were analysed using the analytical solution SciVal. Network analysis of the observed topics and authors was performed applying VOSviewer 1.6.16.

Citation maps were built for the top 5 leading publications (by the number of citations). About 1548 works cite the top 5 leading publications. For these publications, VOSviewer 1.6.16 network maps of joint citation and topics of research networks of the authors of the works were formed. When constructing the maps, the association strength normalisation method was used. The authors merged small clusters using the min cluster size filter. 


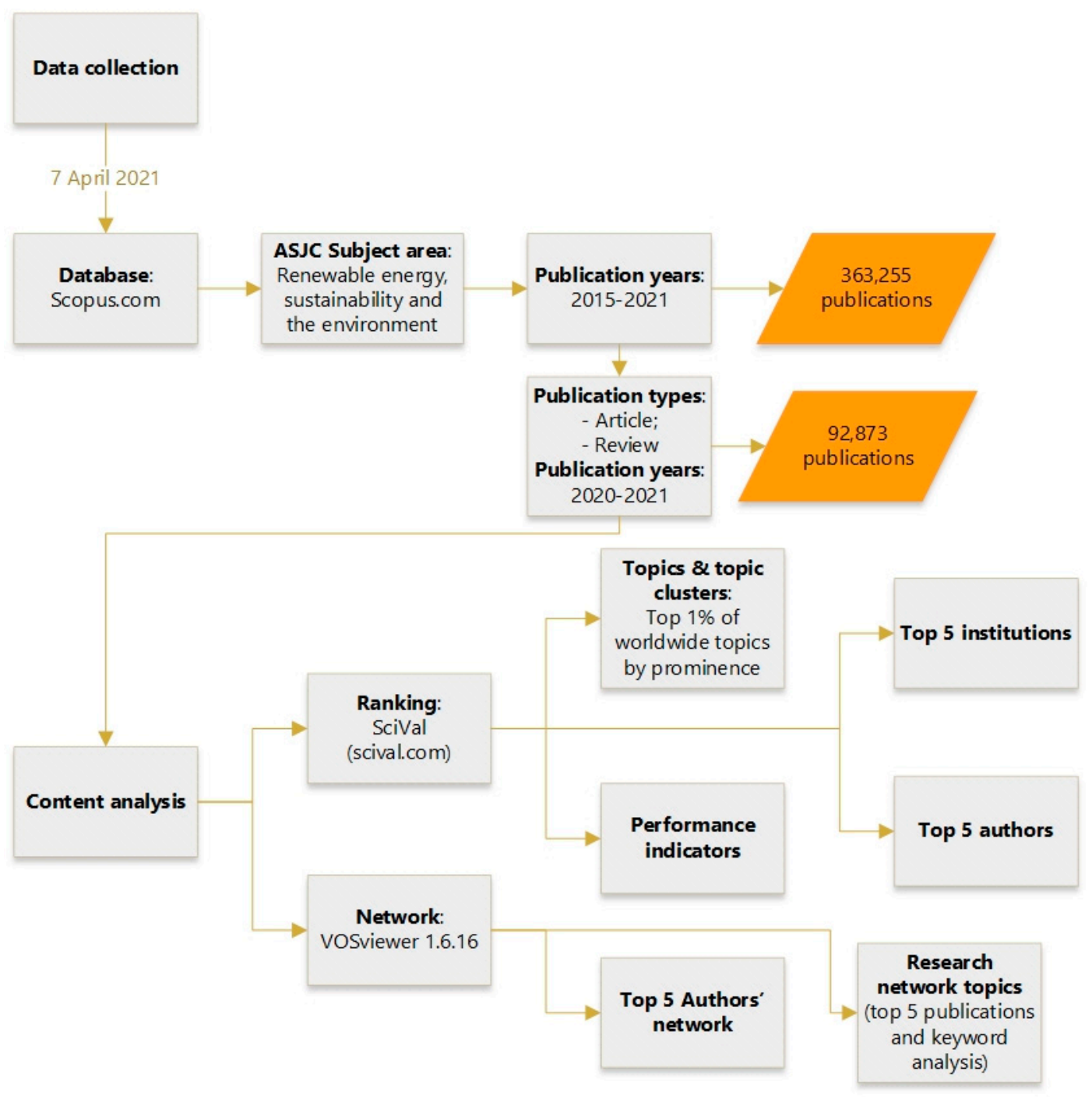

Figure 1. Diagram of the general research methodology.

\section{Results and Discussion}

\subsection{The Cluster Analysis}

The authors analysed the clusters and topics included in the subject area 'Renewable Energy, Sustainability and the Environment' for works published in 2020-2021. All publications during this period can be grouped into 20 clusters, three of which belonged to the top $1 \%$ of worldwide clusters by prominence in the Scopus database. These are such ASJC topic clusters (TC) as TC.30, TC.28, TC.81 (Table 1). The TC.30 contains 52 topics, the most important in terms of prominence percentile are topics (T) T.4025, T.1727, T.6, T.350 and T.5899. In the TC.28, topics T.257, T.200, T.5522 should be distinguished by prominence, and in the TC.81-topics T.5457, T.2456, T.3285. It is clear that the subject of these publications mainly relates to such areas as energy, materials science, chemistry. Although research within these clusters is being conducted worldwide, scientists from China and the United States have made the most significant progress. 
Table 1. Top $1 \%$ of worldwide clusters by prominence that appear within renewable energy, sustainability and the environment, 2020-2021.

\begin{tabular}{ccccc}
\hline Topic Cluster & $\begin{array}{c}\text { Scholarly } \\
\text { Output }\end{array}$ & $\begin{array}{c}\text { Publication Share } \\
\mathbf{( \% )}\end{array}$ & $\begin{array}{c}\text { Field-Weighted } \\
\text { Citation Impact }\end{array}$ & $\begin{array}{c}\text { Prominence } \\
\text { Percentile }\end{array}$ \\
\hline $\begin{array}{c}\text { Secondary Batteries; Electric Batteries; } \\
\text { Lithium Alloys (TC.30) }\end{array}$ & 7891 & 6.90 & 1.96 & 100.000 \\
$\begin{array}{c}\text { Electric Power Transmission Networks; Wind } \\
\text { Power; Electric Power Distribution (TC.28) }\end{array}$ & 6251 & 7.23 & 1.00 & 99.398 \\
Electricity; Energy; Economics (TC.81) & 3728 & 7.40 & 1.60 & 99.264 \\
\hline
\end{tabular}

Based on the SciVal database (www.scival.com, accessed on 7 April 2021); data source: Scopus (downloaded on 7 April 2021); copyright: Elsevier B.V.

According to the analytical platform SciVal, this sample of publications contained a total of 825 ASJC topics, 135 topics of which were in the top 1\% of worldwide topics by prominence. Among the topics in the sample, one topic had 100\% prominence (Figure 2, Table 2). This is T.20 (TC.8), which is related to the study of perovskite photovoltaic cells for solar panels. This topic is prospective and developing rapidly.

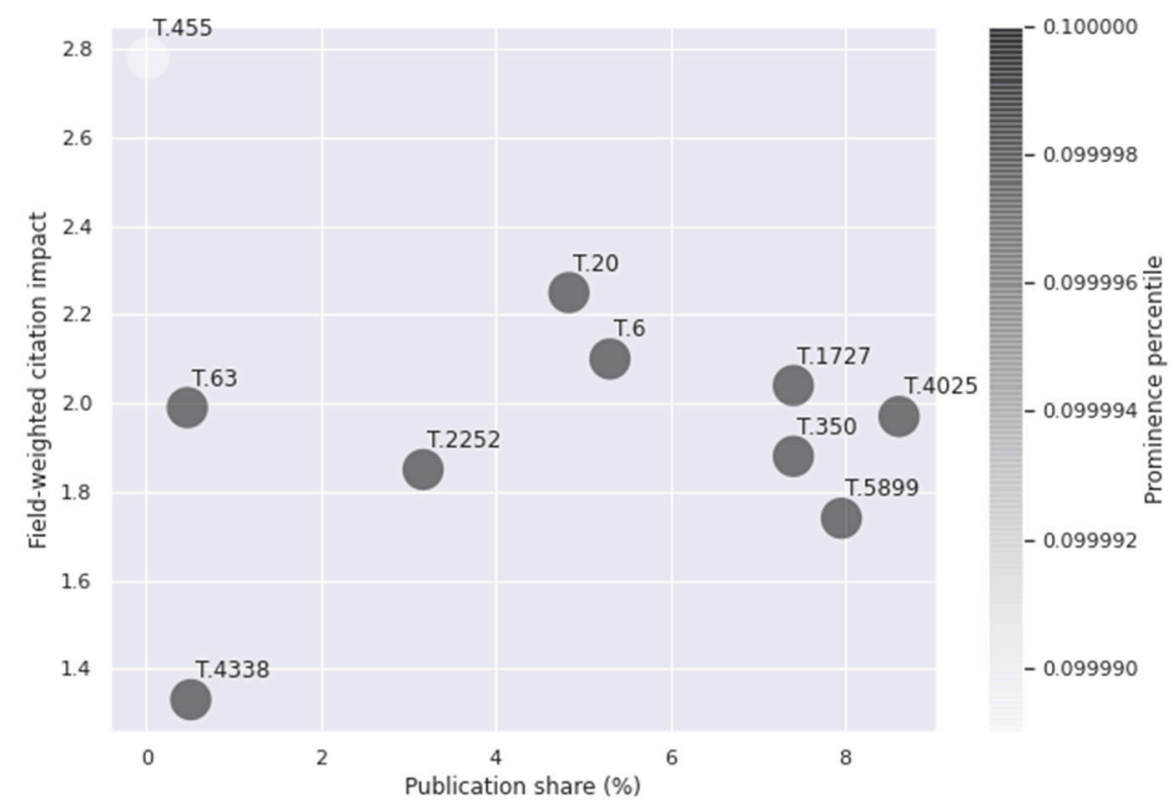

Figure 2. Top 10 topics by prominence that appear within renewable energy, sustainability and the environment, 2020-2021 (Based on the SciVal database (www.scival.com, accessed on 7 April 2021); data source: Scopus (downloaded on 7 April 2021); copyright: Elsevier B.V.). 
Table 2. Top 10 topics by prominence ranking that appear within renewable energy, sustainability and the environment, 2020-2021.

\begin{tabular}{|c|c|c|c|c|}
\hline Rank & Topic & $\begin{array}{l}\text { Prominence } \\
\text { Percentile }\end{array}$ & Top First Authors by Citations & $\begin{array}{l}\text { Top First Source by } \\
\text { Citations }\end{array}$ \\
\hline 1 & $\begin{array}{c}\text { Perovskite Solar Cells; Lead Bromide; } \\
\text { Formamidine [T.20] }\end{array}$ & 100.000 & Zheng, X., Hou, Y., Bao, C. and 27 more & Nature Energy \\
\hline 2 & Object Detection; CNN; IOU [T.4338] & 99.999 & Rashid, M., Khan, M.A., Alhaisoni, M. and 4 more & $\begin{array}{l}\text { Sustainability } \\
\text { (Switzerland) }\end{array}$ \\
\hline 3 & $\begin{array}{l}\text { Oxygen Production; Electrocatalysts; } \\
\text { Water Splitting [T.4025] }\end{array}$ & 99.997 & Liang, C., Zou, P., Nairan, A. and 7 more & $\begin{array}{l}\text { Energy and } \\
\text { Environmental } \\
\text { Science }\end{array}$ \\
\hline 4 & $\begin{array}{c}\text { Cyanogen; Heptazine; Photocatalysts } \\
\text { [T.2252] }\end{array}$ & 99.996 & Che, H., Liu, C., Che, G. and 5 more & Nano Energy \\
\hline 5 & $\begin{array}{l}\text { Molybdenum Disulfide; Rhenium } \\
\text { Sulfide; Van Der Waals [T.63] }\end{array}$ & 99.995 & Bafekry, A., Obeid, M.M., Nguyen, C.V. and 2 more & $\begin{array}{l}\text { Journal of Materials } \\
\text { Chemistry A }\end{array}$ \\
\hline 6 & $\begin{array}{c}\text { Sodium-ion Batteries; Nati2(Po4)3; Ion } \\
\text { Storage [T.1727] }\end{array}$ & 99.994 & Guo, R., Lv, C., Xu, W. and 7 more & $\begin{array}{l}\text { Advanced Energy } \\
\text { Materials }\end{array}$ \\
\hline 7 & $\begin{array}{l}\text { Electrochemical Capacitors; Cobaltous } \\
\text { Sulfide; Electrode Materials [T.6] }\end{array}$ & 99.993 & $\begin{array}{l}\text { Wulan Septiani, N.L., Kaneti, Y.V., Fathoni, K.B. and } \\
9 \text { more }\end{array}$ & Nano Energy \\
\hline 8 & $\begin{array}{c}\text { Intestine Flora; Ruminococcaceae; } \\
\text { Dysbiosis [T.455] }\end{array}$ & 99.992 & Tashiro, A., Shaw, R. & $\begin{array}{l}\text { Sustainability } \\
\text { (Switzerland) }\end{array}$ \\
\hline 9 & $\begin{array}{l}\text { Zinc Air Batteries; Electrocatalysts; } \\
\text { Chemical Reduction [T.350] }\end{array}$ & 99.991 & Zhu, Y., Sokolowski, J., Song, X. and 3 more & $\begin{array}{l}\text { Advanced Energy } \\
\text { Materials }\end{array}$ \\
\hline 10 & $\begin{array}{l}\text { Electrocatalysts; Cobalt Phosphide; } \\
\text { Water Splitting [T.5899] }\end{array}$ & 99.989 & Wu, Q., Luo, M., Han, J. and 7 more & ACS Energy Letters \\
\hline
\end{tabular}

Based on the SciVal database (www.scival.com, accessed on 7 April 2021); data source: Scopus (downloaded on 7 April 2021); copyright: Elsevier B.V.

In general, the most cited publications in the research topics (Table 2) were prepared by both small teams and quite powerful ones, consisting of 30 people. Moreover, about $27 \%$ of all teams were international (Figure 3 ). However, at the same time, only $3 \%$ of co-authors had both an academic and a corporate affiliation, which may be a symptom of some slowdown in the commercialisation of innovations.

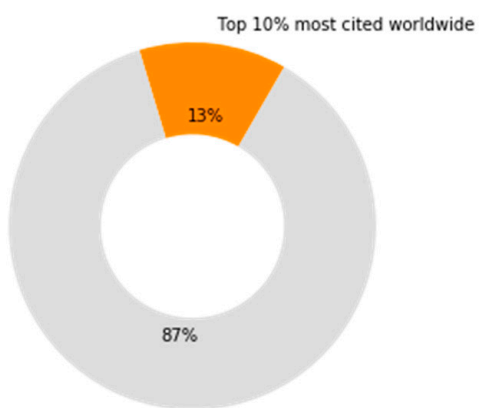

Other publications

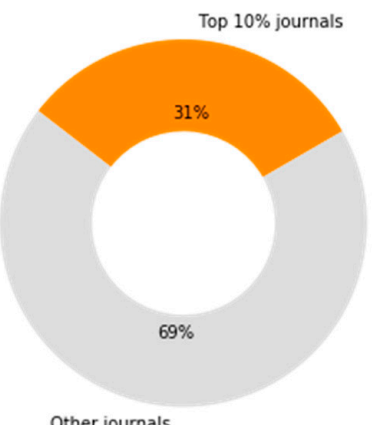

Other journals

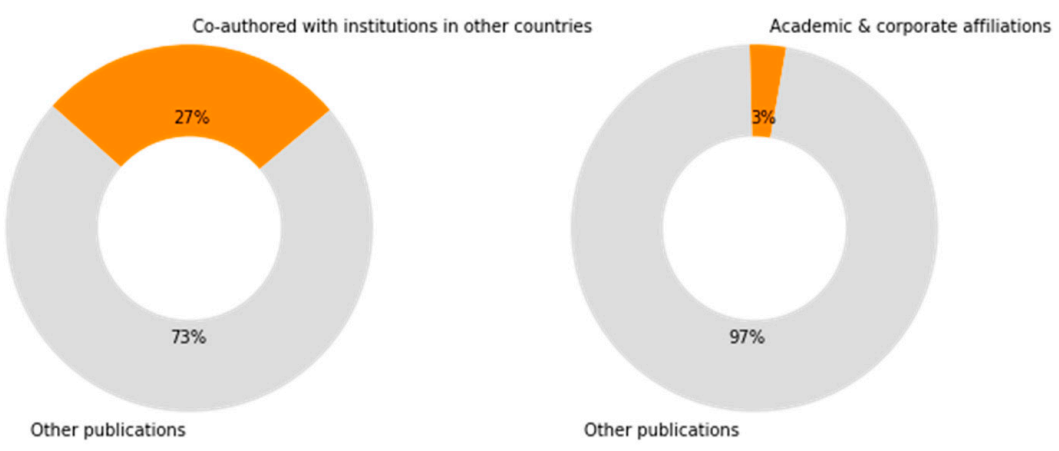

Figure 3. Performance indicators within renewable energy, sustainability and the environment, 2020-2021 (Based on the SciVal database (www.scival.com, accessed on 7 April 2021); data source: Scopus (downloaded on 7 April 2021); copyright: Elsevier B.V.). 
At the same time, $31 \%$ of publications in the sample belonged to the top $10 \%$ of journals. Most publications were published in 5 journals (Table 3): Sustainability (13,340 publications), Journal of Cleaner Production (7021), Energies (5368), International Journal of Hydrogen Energy (4382), Renewable Energy (3353). However, the most cited were publications published in the journals Nature Energy (14.3 citations per publication in the set), Energy and Environmental Science (11.4), Advanced Energy Materials (8.1), Energy Storage Materials (8.1). It is clear that the journals Nature Energy and Energy and Environmental Science have the highest score on the 2019 index CiteScore ${ }^{\mathrm{TM}}$ (Appendix A, Table A1).

Table 3. Top 10 Scopus sources by publications on renewable energy, sustainability and the environment in 2020-2021.

\begin{tabular}{cccc}
\hline Scopus Source & Publications & Citations Per Publication $^{\text {2019 }}$ & CiteScore $^{\mathrm{TM}}$ \\
\hline Sustainability & 13,340 & 1.4 & 3.2 \\
Energies & 7021 & 4.2 & 10.9 \\
Journal of Cleaner Production & 5368 & 1.5 & 3.8 \\
International Journal of Hydrogen & 4382 & 2.9 & 8.0 \\
Energy & 3353 & 4.5 & 11.2 \\
Renewable Energy & 2594 & 4.1 & 17.1 \\
Journal of Materials Chemistry A & 2152 & 2.9 & 9.7 \\
ACS Sustainable Chemistry and & 2085 & 4.1 & 12.8 \\
Engineering & 1934 & 3.4 & 14.4 \\
Bioresource Technology & 1813 & 1.5 & 5.8 \\
Journal of Power Sources & & \\
\hline
\end{tabular}

Based on the SciVal database (www.scival.com, accessed on 7 April 2021); data source: Scopus (downloaded on 7 April 2021); copyright: Elsevier B.V.

\subsection{Institutions' Research Performance}

In terms of quantitative indicators of institutions for scientific publications in this area, the absolute leaders are Chinese institutions, which in the top ten occupy nine places in terms of the number of publications. The top 10 institutions by scientific result (scholarly output) are headed by the Ministry of Education of China, with affiliation of which 3377 publications were published in 2020-2021. Among the 9062 authors affiliated with the Ministry of Education of China, the largest number of publications was in Liao Q. (27 publications), Zhu X. (22) and Wang G. (15).

However, if we study the number of citations per one publication, the picture will be completely different. According to this metric, the top five institutions include Fluxim AG (Switzerland), International Union for Conservation of Nature and Natural Resources (Switzerland), Royal Swedish Academy of Sciences (Sweden), Valparaiso University (USA), Cag University (Turkey). These institutions belong to different countries and regions, and to different sectors. The top five includes government, corporate and academic institutions. It is worth noting that according to this metric, only institutions with a few highly cited works were in the top (Table 4).

Table 4. Top 5 institutions by number of citations per publication in Scopus on renewable energy, sustainability and the environment in 2020-2021.

\begin{tabular}{ccccc}
\hline Institution & Citations & Authors & $\begin{array}{c}\text { Citations Per } \\
\text { Publication }\end{array}$ & $\begin{array}{c}\text { Field-Weighted Citation } \\
\text { Impact (SciVal) }\end{array}$ \\
\hline $\begin{array}{c}\text { Fluxim AG } \\
\text { International Union for }\end{array}$ & 130 & 6 & 43.3 & 16.52 \\
$\begin{array}{c}\text { Conservation of Nature and } \\
\text { Natural Resources }\end{array}$ & 86 & 3 & 28.7 & 16.45 \\
Royal Swedish Academy of & 92 & 4 & 23.0 & 12.97 \\
$\quad$ Sciences & 107 & 3 & 21.4 & 8.12 \\
Valparaiso University & 108 & 3 & 18.0 & 6.96 \\
$\quad$ Cag University & & & \\
\hline
\end{tabular}

Based on the SciVal database (www.scival.com, accessed on 7 April 2021); data source: Scopus (downloaded on 7 April 2021); copyright: Elsevier B.V. 
Assessing the level of international cooperation in writing scientific publications, it is clear that Chinese institutions prevail. Two Chinese institutions (Chinese Academy of Sciences, and Ministry of Education, China) and one French institution (Center national de la recherche scientifique, CNRS) had the largest number of publications co-authored with employees of foreign institutions in 2020-2021. The Sankey chart provides information on the affiliation of the leading foreign co-authors of these institutions (Figure 4). One can see several directions of geographical orientation: Asian (besides China, you can also name Hong Kong, Singapore, Japan), American (USA and Canada), European (except France, also Great Britain, Denmark, Spain), Australian and African (Tunisia).

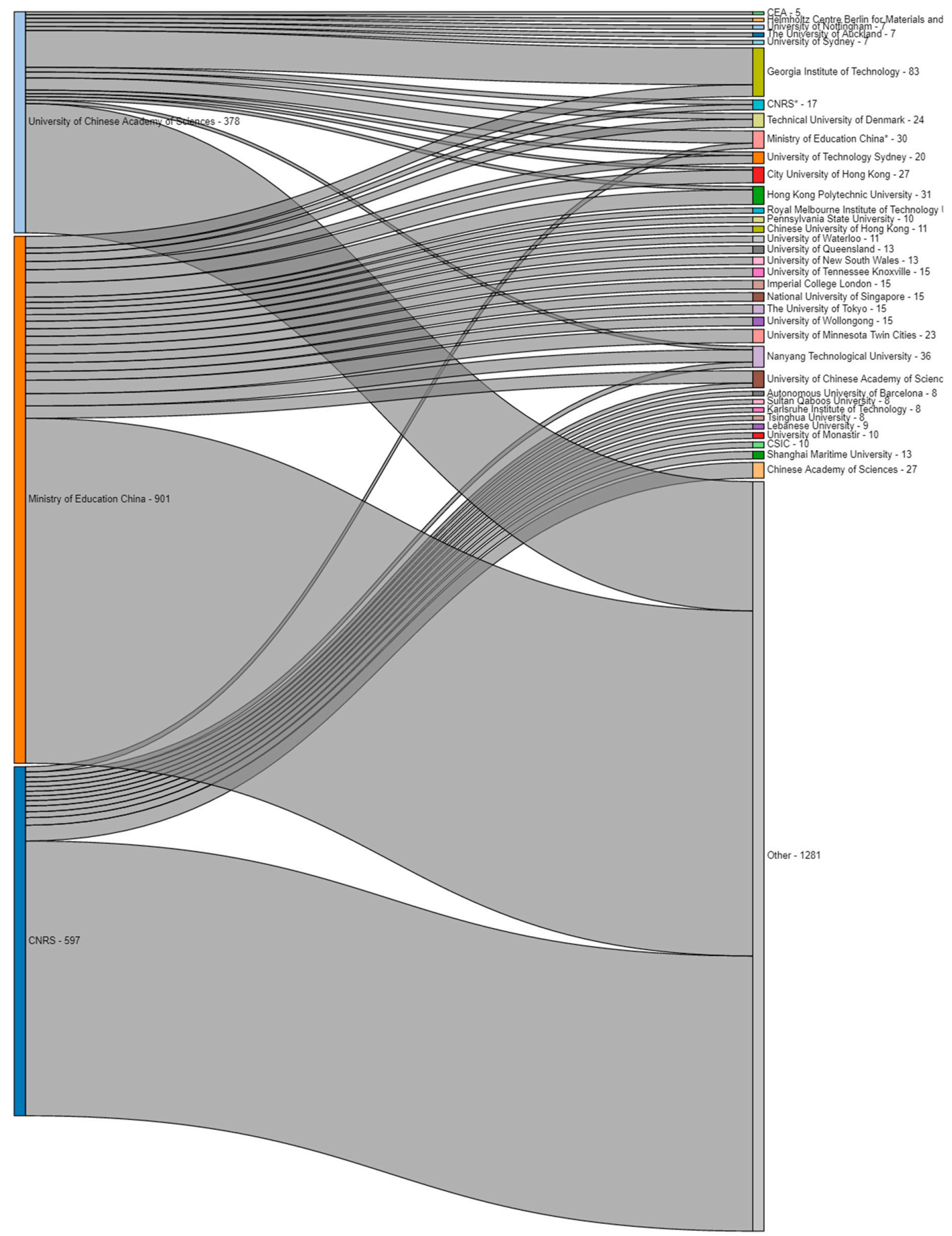

Figure 4. Top networks that appear within renewable energy, sustainability and the environment, 2020-2021 (Based on the SciVal database (www.scival.com, accessed on 7 April 2021); data source: Scopus (downloaded on 7 April 2021); copyright: Elsevier B.V.). 


\subsection{Authors' Topic Research}

In the context of the scientific achievements in the subject area 'Renewable Energy, Sustainability and the Environment' it is also reasonable to analyse the authors' contribution. If we observe the top 10 most cited publications in this field in 2020, it is possible to see the geographical distribution of the relationship between publications (Figure 5). According to the results of spatial clustering, five clusters of countries were identified, the researchers of which have joint publications. The first cluster consisted of 15 countries, and related to assessing the stability of perovskite solar cells. The second cluster included studies of solar cells and modules, but included scientists from 4 countries: Australia, Germany, Italy and Japan. The third cluster of countries included researchers from the United States who had the largest number of links with foreign partners (22 links in this sample of publications). The fourth and fifth clusters included two countries each, China and Hong Kong in the fourth cluster, and India and Turkey in the fifth.

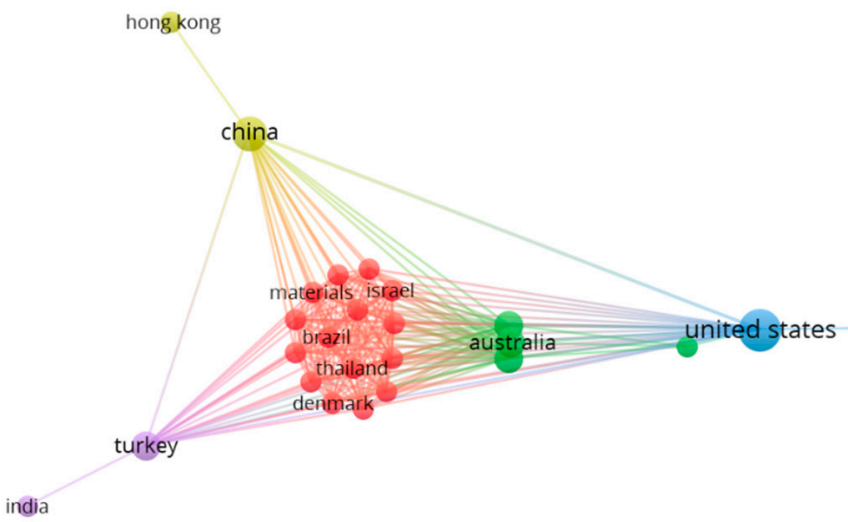

Figure 5. Network map for spatial measurement of research top 10 publications on renewable energy, sustainability and the environment, 2020 (Based on the SciVal database (www.scival.com, accessed on 7 April 2021); data source: Scopus (downloaded on 7 April 2021); copyright: Elsevier B.V.).

In general, the most cited works dealt with the security, efficiency and reliability of separate elements of energy systems in 2020-2021. Most works of the different areas studied energy storage issues, solar cells and their components (Table 5). It can be seen in more detail by looking at the topics of research networks.

Table 5. Top 5 authors by the number of citations in Scopus on renewable energy, sustainability and the environment in 2020-2021.

\begin{tabular}{|c|c|c|c|c|}
\hline Name & Country & $\begin{array}{l}\text { Citations } \\
(2020 / 21)\end{array}$ & $\begin{array}{l}\text { Scholarly Output } \\
\qquad(2020 / 21)\end{array}$ & Most Cited Publication (2020/21) \\
\hline Wang, Zhonglin & China, USA & 601 & 41 & $\begin{array}{l}\text { On the first principle theory of nanogenerators } \\
\text { from Maxwell's equations }\end{array}$ \\
\hline Sun, Andy Xueliang & Canada & 511 & 43 & $\begin{array}{l}\text { Design of a mixed conductive garnet/Li interface } \\
\text { for dendrite-free solid lithium metal batteries }\end{array}$ \\
\hline $\begin{array}{c}\text { Jermsittiparsert, } \\
\text { Kittisak }\end{array}$ & Thailand & 399 & 46 & $\begin{array}{l}\text { An IGDT-based risk-involved optimal bidding } \\
\text { strategy for hydrogen storage-based intelligent } \\
\text { parking lot of electric vehicles }\end{array}$ \\
\hline Shafee, Ahmad & Viet Nam & 379 & 12 & $\begin{array}{l}\text { Acceleration of discharge process of clean energy } \\
\text { storage unit with insertion of porous foam } \\
\text { considering nanoparticle enhanced paraffin }\end{array}$ \\
\hline Lü, Xinhui & Hong Kong & 362 & 16 & $\begin{array}{c}\text { Over } 17 \% \text { efficiency ternary organic solar cells } \\
\text { enabled by two non-fullerene acceptors working } \\
\text { in an alloy-like model }\end{array}$ \\
\hline
\end{tabular}

Based on the SciVal database (www.scival.com, accessed on 7 April 2021); data source: Scopus (downloaded on 7 April 2021); copyright: Elsevier B.V. 
To this end, the authors identified 1548 works citing the top 5 leading publications. For these publications, VOSviewer 1.6.16 network maps of joint citation (Figure 6) and topics of research networks of the authors of the works (Figure 7) were formed. The online citation map visually shows 59 authors who cited the top 5 leading publications more than 15 times in 2020-2021. The most prominent author in this regard was the Chinese scientist Li Y., who had a binding force of 118 for 54 documents. The author's network focused on collaboration with colleagues from the College of Materials Science and Engineering, Hunan University (China), studying high-density potassium ion batteries.

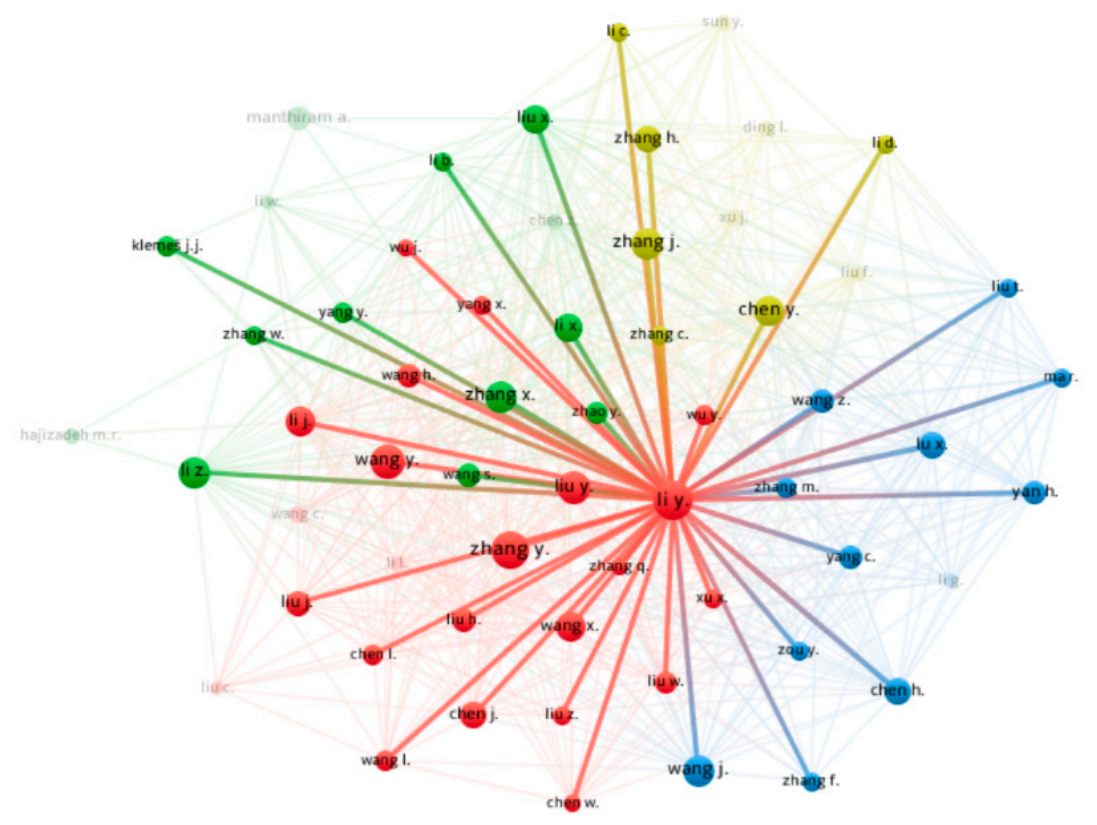

Figure 6. Network citation map of top 5 publications on renewable energy, sustainability and the environment, 2020-2021 (Based on the SciVal database (www.scival.com, accessed on 7 April 2021); data source: Scopus (downloaded on 7 April 2021); copyright: Elsevier B.V.).

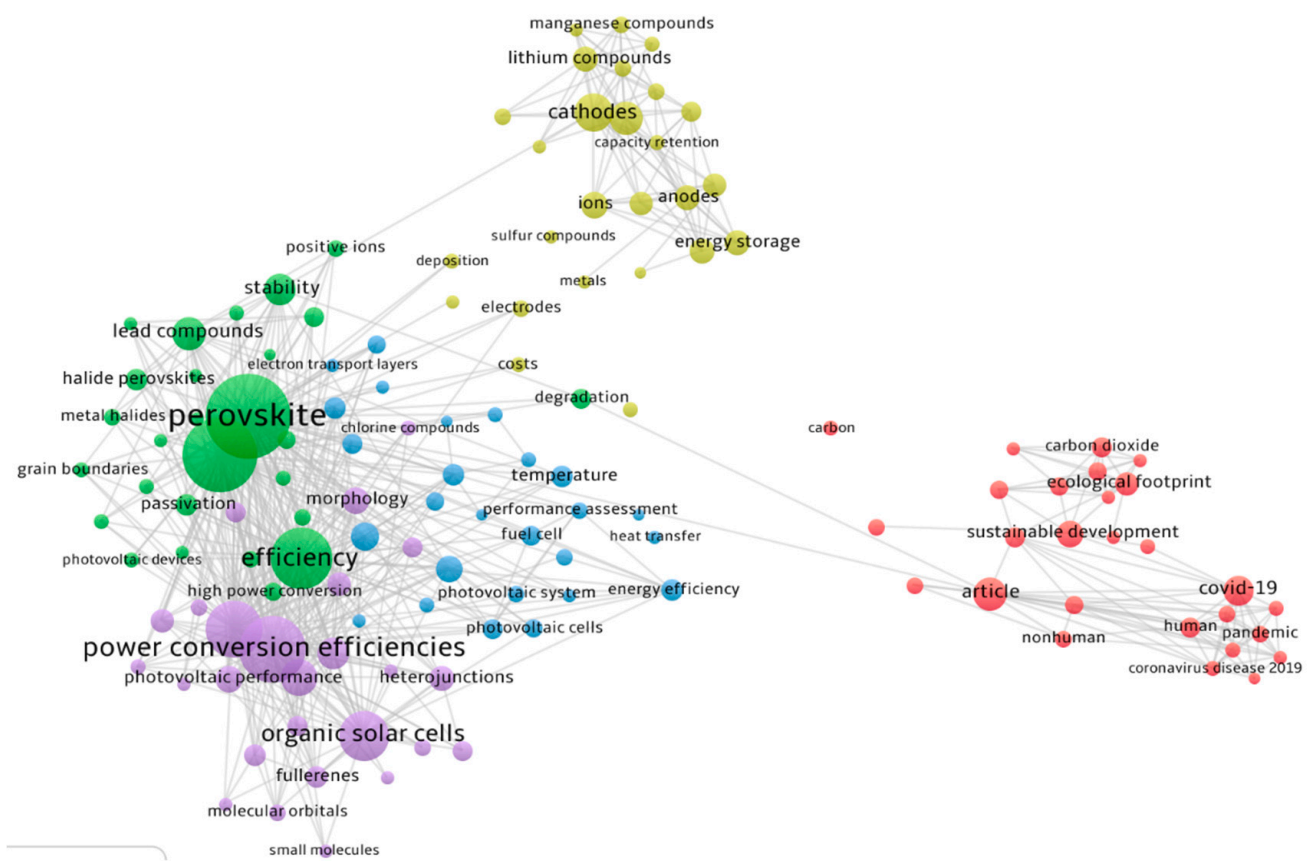

Figure 7. Network map of research topics for the top 5 publications on renewable energy, sustainability and the environment, 2020-2021 (Based on the SciVal database (www.scival.com, accessed on 7 April 2021); data source: Scopus (downloaded on 7 April 2021); copyright: Elsevier B.V.). 
As a result of the contextual analysis (Figure 7), a separate research direction in the first cluster was identified. Some works included in the first cluster observed the causes (SARS-CoV-2), results and consequences of coronavirus disease (COVID-19) along with the use of renewable energy sources. In combination with the sustainable development goals research, scientists tried to find an ecological footprint of the pandemic, better to manage waste and to form new trends in ecological research.

The terms included in the research of perovskite solar panels are concentrated in the second cluster. These terms had the most significant impact on the sample (total link strength was 2458 units). In combination with the main topic, the scientist paid attention to efficiency, measurement of degradation, defects and limitations of solar panels. The topics of long-term and operational stability of elements, photovoltaic devices, optoelectronic technologies $[62,63]$ were also studied.

The third cluster contained works focusing on the study of semiconductors, silicone, nanostructured materials, nanofluidics. Performance assessments for green energy transformation were evaluated.

The fourth cluster considered various technologies to use batteries and accumulators of clean energy, capacity retention, assessment and ensuring the stability of space in the management of high-energy densities.

The fifth cluster included studies of energy gaps that the authors tried to bridge with efficient energy conversion technologies. Most works in the cluster were related to the development of organic solar panels.

\subsection{Computer Science Research Domain in Renewable Energy, Sustainability and the Environment}

Emerging research on renewable energy, sustainability and the environment coincide with a dynamic development of information technologies and computer science methods, which support the conducted research by modelling, prognosis, optimisation and computer simulations solutions. According to SCOPUS sources, for the last two years (2020-2021), only a very selected number (443) of documents covered simultaneously all the aspects, namely renewable energy, sustainability and the environment, with the aid of computer science techniques. On the other hand, bilateral correlations between computer science and individual subdomains: renewable energy, sustainability and the environment, respectively, have a much greater representation, reaching tens of thousands of scholarly outputs, in the last two years.

Considering synergy between renewable energy and computer science research domains, the most cited scholarly outputs, considering this research field, investigate photovoltaic cells parameters optimisation. The power system frequency stabilisation subdomain was the most cited [64]. Another research subdomain, second in citation order, covers renewable energy smart grid systems [65]. The most extensively exploited computer science methods encompass machine learning techniques, blockchain technology and edge computing, which increase the intelligence of smart grid nodes, support the security of energy systems and reduce a transferred data stream.

Analogically, the computer science research domain, in the context of sustainability, encompasses thousands of scholarly outputs. The most cited prevailing problems regard blockchain and machine learning techniques in sustainable supply chains and transportation policies [66-68]. The research subdomain also puts a particular interest in the exploitation of big data techniques and Edge-IoT systems for ecosystems monitoring [69], damage detection [70] and livestock or crops monitoring [71]. Surprisingly, sustainable human-centric healthcare and distant education systems [72,73], which intuitively may inspire scientists, due to the recent pandemic situation, in the last two years, give way to the logistics-related problems. Data science techniques and artificial intelligence can support ecological design, which accelerates the transition towards a regenerative approach [74] or can support energy management and sharing among base stations [75].

According to the SCOPUS sources, the most extensive scope of scholarly outputs regards exploiting computer science techniques and methods in environmental engineering- 
related problems. The dominating research subdomain considers wireless networks [76]. It might be caused by the growing importance of the $5 \mathrm{G} / 6 \mathrm{G}$ technologies in communication and IoT distributed $[77,78]$, covering edge computing and industrial sensors clouds. Second, in citation rate, research problems concern computer science techniques in autonomous vehicles software [79]. Besides widely explored aspects of roads static vicinity (i.e., signposts) analysis [80], geo-localisation and route planning [81], the most challenging and at the same time revealing great room for research-based impact refers to predicting the behaviour of a dynamic, unpredictably changing environment [82].

Artificial intelligence techniques for energy consumption or savings prediction [83] are among the most cited problems in the renewable energy engineering research domains. They are almost as much investigated as the aspects of robust grid energy management or optimal deployment of zero-net-energy systems [84,85].

The maps of pairwise research topics, encompassing computer science methods in selected subdomains are presented in Figure 8. Although individual research subdomains are developing very dynamically, their interdependences are relatively limited. Based on this, it can be concluded that the application of IT methods in the field of green energy and sustainability will steadily increase in the coming years.

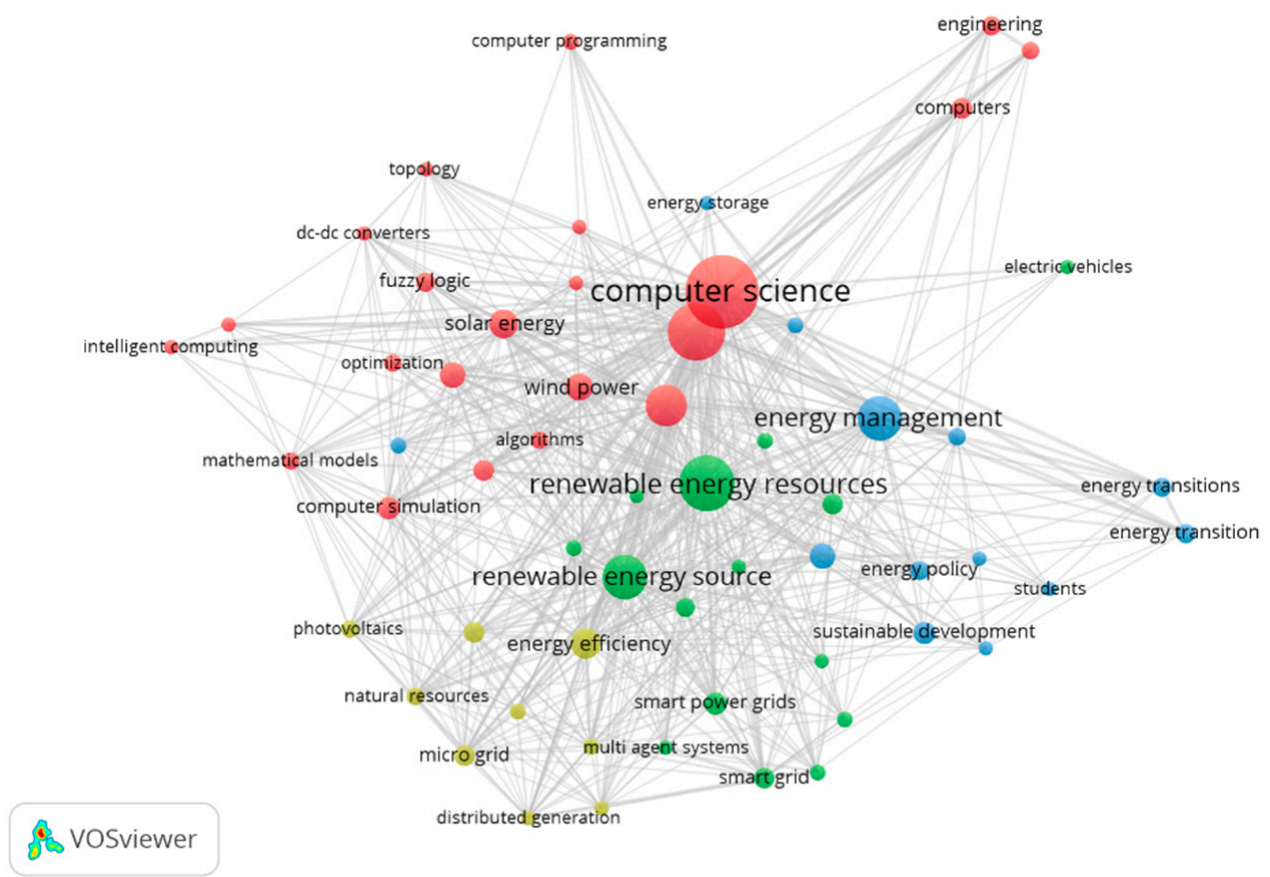

(a)

Figure 8. Cont. 


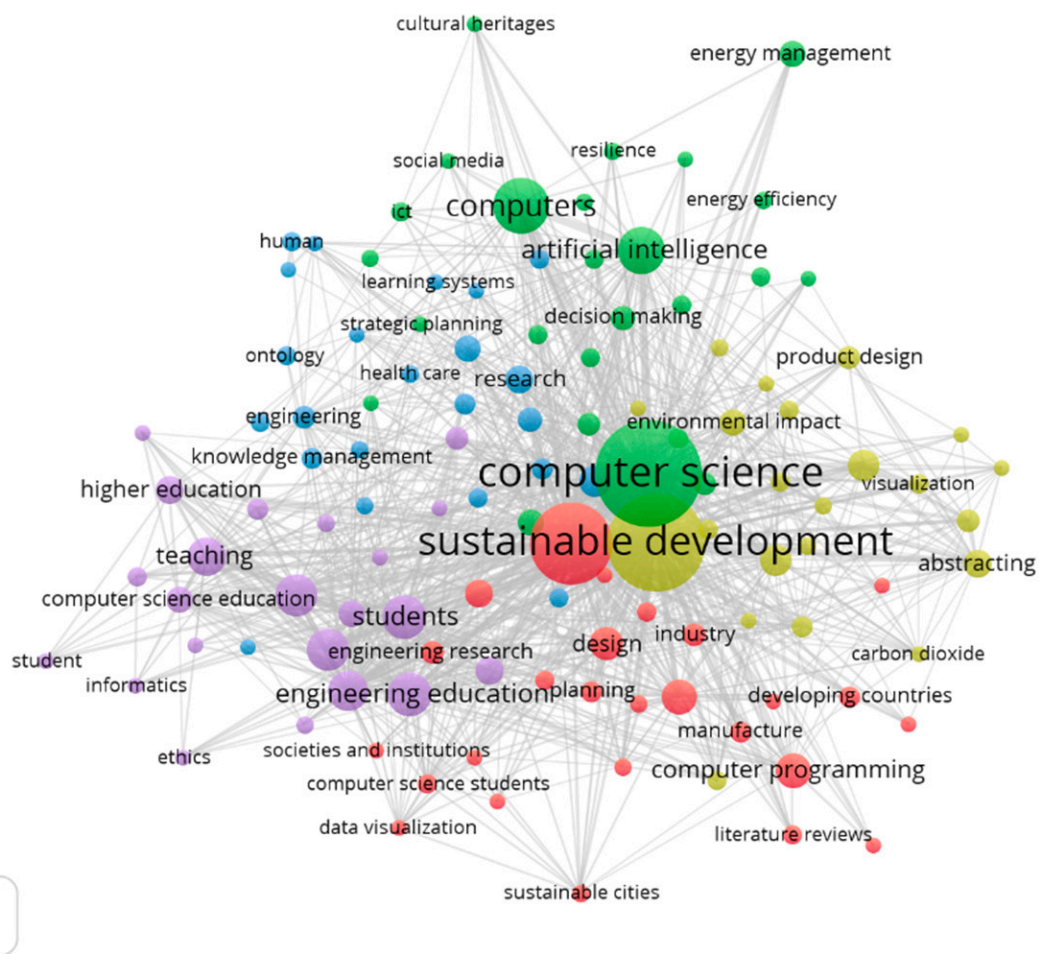

(b)

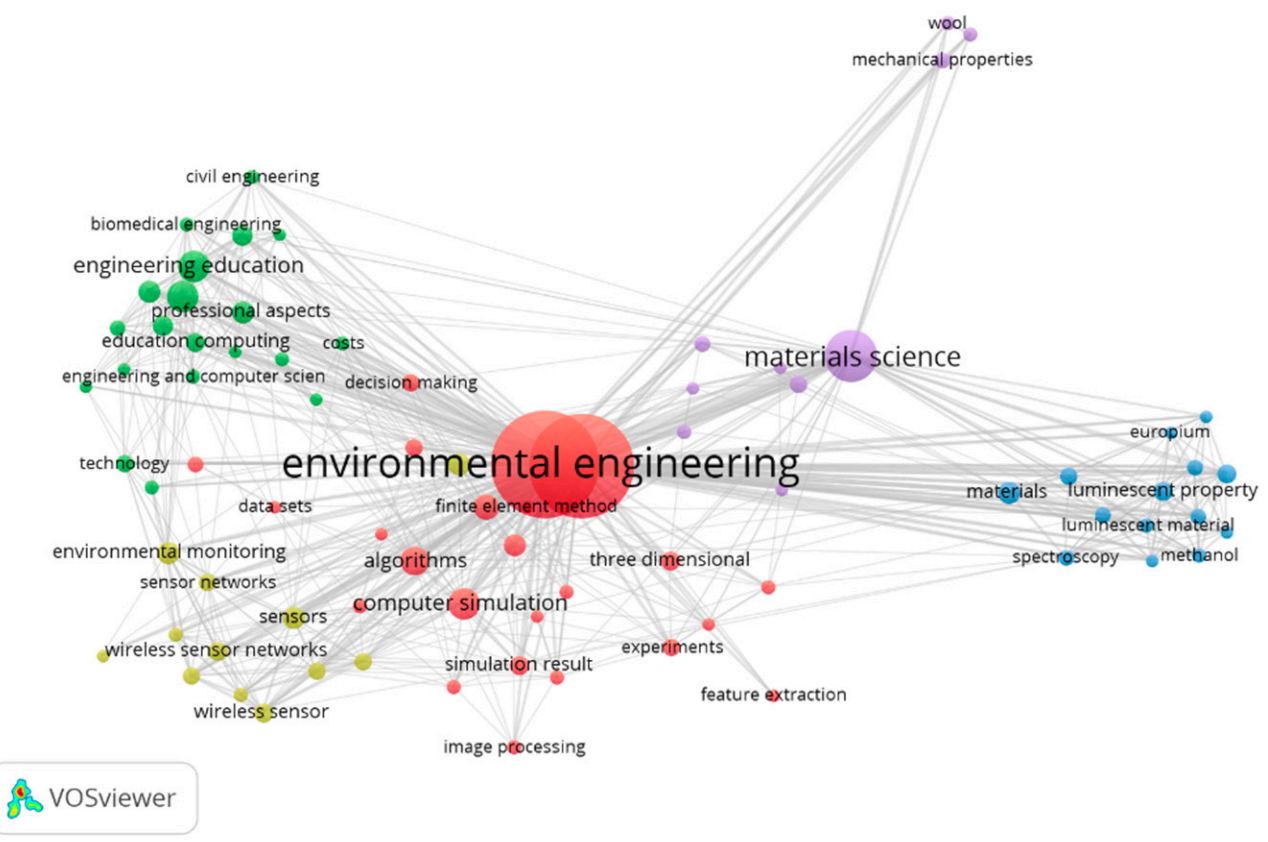

(c)

Figure 8. Network map covering computer science and (a) renewable energy, (b) sustainability, (c) the environmental engineering research subdomains, 2020-2021 (data source: Scopus (downloaded on 7 April 2021); copyright: Elsevier B.V.; graphics according to Kamada-Kawai layout).

\section{Conclusions}

The study aimed to identify the general trends in research in the subject area 'Renewable energy, sustainability and the environment'. The general research question is answered 
by exploring the scientific publications for 2020-2021. To this end, 92,873 publications by 302,587 authors, published in 123 sources and indexed by the Scopus database as of 7 April 2021, were analysed. Applications of visualisation of scientific publications data-SciVal and VOSviewer were used for the analysis of the newest subjects and clusters, research of establishments and the leading authors of analytical works.

The data showed that all publications during this period were grouped into 20 clusters (ASJC), three of which belonged to the top $1 \%$ of the world's clusters by popularity: TC.30, TC.28, TC.81. Among the topics in the sample, one topic had the $100 \%$ prominence, related to the study of perovskite photovoltaic cells for solar panels (T.20). About $31 \%$ of publications in the sample belonged to the top $10 \%$ of journals. However, at the same time, only $3 \%$ of co-authors had both an academic and a corporate affiliation, which may be a symptom of some slowdown in the commercialisation of innovations.

In terms of the number of scientific publications in this field, the absolute leaders are Chinese institutions. They take nine places in the top ten in terms of the number of published works for 2020-2021. The largest number of publications co-authored with employees from foreign institutions in 2020-2021 had two Chinese institutions (Chinese Academy of Sciences, and Ministry of Education, China) and one French (CNRS).

In general, in 2020-2021, the most cited works were those mainly by authors from the Asian region, which were devoted to security, efficiency and reliability of individual elements in the energy systems, the study of COVID disease along with the renewable energy sources, perovskite and organic solar panels, nanostructured materials and high energy density.

The review is enhanced by a contextual analysis of areas of collaboration between two rapidly growing disciplines: computer science and the fields of renewable energy, sustainability and environmental engineering. Its results clearly show that the undeveloped space of cooperation between the disciplines will be a stimulator of their mutual development and a source of many new solutions in the coming years.

Author Contributions: Conceptualisation, S.K., A.W. and T.V.; methodology, S.K. and A.W.; software, S.K.; validation, S.K.; formal analysis, S.K. and M.M.; investigation, S.K. and A.W.; resources, S.K., Y.B.; data curation, S.K., Y.B. and S.K.; writing—original draft preparation, S.K.; writing-review and editing, S.K., A.W. and T.V.; visualisation, S.K.; supervision, T.V. and A.W.; funding acquisition, S.K., A.W. and T.V. All authors have read and agreed to the published version of the manuscript.

Funding: This research was funded by the National Research Foundation of Ukraine (grant numbers: 2020.02/0231; 2020.01/0185); the Ministry of Education and Science of Ukraine (grant number: 0119U100766). This research was carried out as a part of project no. POIR.01.01.01-00-0281/20-00, entitled: 'Predictive energy management system EnMS', co-financed by the National Center for Research and Development in Poland.

Institutional Review Board Statement: Not applicable.

Informed Consent Statement: Not applicable.

Data Availability Statement: Not applicable.

Acknowledgments: Authors appreciate the copyright holder: (C) Elsevier B.V. as well as the source of the extracted data which is SciVal @ www.scival.com (accessed on 7 April 2021).

Conflicts of Interest: The authors declare no conflict of interest. The funders had no role in the design of the study; in the collection, analyses, or interpretation of data; in the writing of the manuscript, or in the decision to publish the results. 


\section{Appendix A}

Table A1. Top 100 Scopus sources by publications on renewable energy, sustainability and the environment in 2020-2021.

\begin{tabular}{|c|c|c|c|}
\hline Scopus Source & Publications & $\begin{array}{l}\text { Citations Per } \\
\text { Publication }\end{array}$ & 2019 CiteScore $^{\mathrm{TM}}$ \\
\hline Sustainability & 13,340 & 1.4 & 3.2 \\
\hline Journal of Cleaner Production & 7021 & 4.2 & 10.9 \\
\hline Energies & 5368 & 1.5 & 3.8 \\
\hline International Journal of Hydrogen Energy & 4382 & 2.9 & 8.0 \\
\hline Renewable Energy & 3353 & 4.5 & 11.2 \\
\hline Journal of Materials Chemistry A & 2594 & 4.1 & 17.1 \\
\hline ACS Sustainable Chemistry and Engineering & 2152 & 2.9 & 9.7 \\
\hline Bioresource Technology & 2085 & 4.1 & 12.8 \\
\hline Journal of Power Sources & 1934 & 3.4 & 14.4 \\
\hline Journal of the Electrochemical Society & 1813 & 1.5 & 5.8 \\
\hline International Journal of Energy Research & 1627 & 1.6 & 4.2 \\
\hline Nano Energy & 1490 & 6.0 & 23.1 \\
\hline Energy Conversion and Management & 1446 & 4.5 & 13.6 \\
\hline Solar Energy & 1354 & 2.6 & 8.1 \\
\hline Journal of Energy Storage & 1187 & 2.8 & 5.2 \\
\hline $\begin{array}{c}\text { Energy Sources, Part A: Recovery, Utilization and } \\
\text { Environmental Effects }\end{array}$ & 1088 & 1.5 & 2.1 \\
\hline Sustainable Cities and Society & 1000 & 4.6 & 7.5 \\
\hline Waste and Biomass Valorization & 966 & 1.7 & 3.6 \\
\hline Environmental Research Letters & 928 & 1.7 & 8.9 \\
\hline Biomass Conversion and Biorefinery & 860 & 1.4 & 3.3 \\
\hline 2020 IEEE 4th Conference on Energy Internet and Energy & & & \\
\hline $\begin{array}{l}\text { System Integration: Connecting the Grids Towards a } \\
\text { Low-Carbon High-Efficiency Eneroy Svstem. EI2 } 2020\end{array}$ & 808 & 0 & 0 \\
\hline Advanced Energy Materials & 755 & 8.1 & 35.4 \\
\hline Taiyangneng Xuebao/Acta Energiae Solaris Sinica & 741 & 0.1 & 0.4 \\
\hline Solar Energy Materials and Solar Cells & 653 & 3.0 & 11.6 \\
\hline Renewable and Sustainable Energy Reviews & 641 & 3.6 & 25.5 \\
\hline IEEE Power and Energy Society General Meeting & 639 & 0.1 & 0 \\
\hline Sustainable Energy and Fuels & 639 & 2.2 & 5.4 \\
\hline Energy Storage Materials & 613 & 8.1 & 16.8 \\
\hline $\begin{array}{l}2020 \text { International Multi-Conference on Industrial } \\
\text { Engineering and Modern Technologies, FarEastCon } 2020\end{array}$ & 576 & 0 & 0 \\
\hline International Journal of Ambient Energy & 544 & 2.9 & 2.7 \\
\hline Proceedings of 2020 IEEE 4th Information Technology, & & & \\
\hline $\begin{array}{l}\text { Networking, Electronic and Automation Control } \\
\text { Conference, ITNEC } 2020\end{array}$ & 531 & 0.3 & 0 \\
\hline Sustainable Energy Technologies and Assessments & 516 & 2.4 & 5.4 \\
\hline Journal of Chemical Technology and Biotechnology & 488 & 1.5 & 4.8 \\
\hline Energy Research and Social Science & 472 & 2.5 & 9 \\
\hline Thermal Science & 469 & 1.0 & 2.5 \\
\hline IET Renewable Power Generation & 464 & 1.0 & 7.6 \\
\hline IEEE Transactions on Sustainable Energy & 437 & 3.6 & 15.7 \\
\hline Biomass and Bioenergy & 434 & 1.5 & 6.6 \\
\hline Journal of Wind Engineering and Industrial Aerodynamics & 434 & 1.6 & 4.9 \\
\hline ACS Energy Letters & 432 & 6.6 & 23.4 \\
\hline $\begin{array}{l}\text { iSPEC 2020-Proceedings: IEEE Sustainable Power and } \\
\text { Energy Conference: Energy Transition and Energy Internet }\end{array}$ & 381 & 0 & 0 \\
\hline Frontiers in Energy Research & 371 & 0.7 & 2.5 \\
\hline
\end{tabular}


Table A1. Cont.

\begin{tabular}{|c|c|c|c|}
\hline Scopus Source & Publications & $\begin{array}{l}\text { Citations Per } \\
\text { Publication }\end{array}$ & 2019 CiteScore $^{\mathrm{TM}}$ \\
\hline \multicolumn{4}{|l|}{ Proceedings-2020 IEEE International Conference on } \\
\hline $\begin{array}{c}\text { Environment and Electrical Engineering and } 2020 \text { IEEE } \\
\text { Industrial and Commercial Power Systems Europe, } \\
\text { EEEIC/I and CPS Europe } 2020\end{array}$ & 349 & 0.3 & 0 \\
\hline $\begin{array}{l}\text { SPE/AAPG/SEG Unconventional Resources Technology } \\
\text { Conference 2020, URTeC } 2020\end{array}$ & 349 & 0.2 & 0 \\
\hline $\begin{array}{l}\text { Proceedings of the 15th IEEE Conference on Industrial } \\
\text { Electronics and Applications, ICIEA } 2020\end{array}$ & 343 & 0.1 & 0 \\
\hline Environmental Progress and Sustainable Energy & 341 & 1.2 & 2.8 \\
\hline Research Journal of Chemistry and Environment & 331 & 0.1 & 0.2 \\
\hline Journal of the Energy Institute & 308 & 3.3 & 6.5 \\
\hline $\begin{array}{l}2020 \text { IEEE International Conference on Power Electronics, } \\
\text { Smart Grid and Renewable Energy, PESGRE } 2020\end{array}$ & 298 & 0.6 & 0 \\
\hline Bioresource Technology Reports & 296 & 1.6 & 1.7 \\
\hline Energy and Environmental Science & 293 & 11.4 & 56 \\
\hline $\begin{array}{l}2020 \text { IEEE/IAS Industrial and Commercial Power System } \\
\text { Asia, I and CPS Asia } 2020\end{array}$ & 289 & 0.1 & 0 \\
\hline Geothermics & 288 & 1.5 & 7 \\
\hline Sustainable Production and Consumption & 277 & 2.1 & 5.1 \\
\hline Materials Today Energy & 277 & 2.6 & 6.2 \\
\hline \multicolumn{4}{|l|}{ Proceedings of the ISES Solar World Congress 2019 and IEA } \\
\hline $\begin{array}{l}\text { SHC International Conference on Solar Heating and } \\
\text { Cooling for Buildings and Industry } 2019\end{array}$ & 276 & 0.1 & 0 \\
\hline Nature Environment and Pollution Technology & 275 & 0.1 & 0.5 \\
\hline $\begin{array}{l}\text { Proceedings of the 3rd International Conference on } \\
\text { Intelligent Sustainable Systems, ICISS } 2020\end{array}$ & 273 & 0 & 0 \\
\hline Biotechnology for Biofuels & 266 & 1.9 & 8.9 \\
\hline Asia-Pacific Journal of Chemical Engineering & 245 & 0.8 & 2.4 \\
\hline $\begin{array}{l}\text { Journal of Energy Resources Technology, Transactions of the } \\
\qquad \text { ASME }\end{array}$ & 239 & 1.3 & 4.4 \\
\hline $\begin{array}{c}2020 \text { Advances in Science and Engineering Technology } \\
\text { International Conferences, ASET } 2020\end{array}$ & 231 & 0.3 & 0 \\
\hline ChemNanoMat & 221 & 1.5 & 5 \\
\hline European Biomass Conference and Exhibition Proceedings & 210 & 0 & 0 \\
\hline Wind Energy & 209 & 1.7 & 6.4 \\
\hline $\begin{array}{l}\text { Proceedings of the International Conference on Electronics } \\
\text { and Sustainable Communication Systems, ICESC } 2020\end{array}$ & 209 & 0.4 & 0 \\
\hline \multicolumn{4}{|l|}{ Proceedings-2020 2nd International Conference on Control } \\
\hline $\begin{array}{c}\text { Systems, Mathematical Modeling, Automation and Energy } \\
\text { Efficiency, SUMMA } 2020\end{array}$ & 204 & 0 & 0 \\
\hline Bioenergy Research & 201 & 1.1 & 4.6 \\
\hline 2020 IEEE PES/IAS PowerAfrica, PowerAfrica 2020 & 198 & 0.1 & 0 \\
\hline $\begin{array}{c}\text { International Journal of Precision Engineering and } \\
\text { Manufacturing-Green Technology }\end{array}$ & 195 & 2.2 & 7.5 \\
\hline $\begin{array}{l}2020 \text { Asia Energy and Electrical Engineering Symposium, } \\
\text { AEEES } 2020\end{array}$ & 192 & 0.1 & 0 \\
\hline Sustainable Development & 190 & 3.7 & 4.9 \\
\hline $\begin{array}{l}\text { 6th IEEE International Energy Conference, } \\
\text { ENERGYCon } 2020\end{array}$ & 190 & 0.1 & 0 \\
\hline Green Energy and Environment & 180 & 1.2 & 9.8 \\
\hline Journal of Renewable and Sustainable Energy & 179 & 0.8 & 3.2 \\
\hline Journal of King Saud University, Engineering Sciences & 174 & 2.4 & 6.8 \\
\hline Journal of Security and Sustainability Issues & 174 & 0.5 & 3.9 \\
\hline
\end{tabular}


Table A1. Cont.

\begin{tabular}{|c|c|c|c|}
\hline Scopus Source & Publications & $\begin{array}{l}\text { Citations Per } \\
\text { Publication }\end{array}$ & 2019 CiteScore $^{\mathrm{TM}}$ \\
\hline Progress in Photovoltaics: Research and Applications & 173 & 5.0 & 16.3 \\
\hline Biofuels & 170 & 2.3 & 3 \\
\hline Nature Sustainability & 169 & 7.6 & 6.8 \\
\hline International Journal of Renewable Energy Research & 168 & 0.8 & 4.4 \\
\hline Journal of Modern Power Systems and Clean Energy & 166 & 1.2 & 6.4 \\
\hline $\begin{array}{c}\text { IEEE Transactions on Green Communications } \\
\text { and Networking }\end{array}$ & 166 & 1.0 & 5.5 \\
\hline $\begin{array}{c}\text { Proceedings-2020 23rd IEEE International Multi-Topic } \\
\text { Conference, INMIC } 2020\end{array}$ & 166 & 0 & 0 \\
\hline Energy Exploration and Exploitation & 164 & 1.2 & 2.9 \\
\hline $\begin{array}{l}2020 \text { 11th Power Electronics, Drive Systems, and } \\
\text { Technologies Conference, PEDSTC } 2020\end{array}$ & 164 & 0.5 & 0 \\
\hline Carbon Letters & 160 & 0.9 & 2.8 \\
\hline International Journal of Sustainable Transportation & 155 & 1.9 & 5.6 \\
\hline Energy and Environment & 152 & 1.4 & 2.4 \\
\hline $\begin{array}{c}2020 \text { 5th International Conference on Smart and Sustainable } \\
\text { Technologies, SpliTech } 2020\end{array}$ & 151 & 0.1 & 0 \\
\hline International Journal of Green Energy & 150 & 0.9 & 2.8 \\
\hline Dianli Jianshe/Electric Power Construction & 149 & 0.2 & 1.2 \\
\hline $\begin{array}{l}2020 \text { 7th International Conference on Energy Efficiency and } \\
\text { Agricultural Engineering, EE and AE 2020-Proceedings }\end{array}$ & 146 & 0 & 0 \\
\hline Sustainable Water Resources Management & 143 & 0.7 & 0 \\
\hline $\begin{array}{l}\text { Proceedings of the World Conference on Smart Trends in } \\
\text { Systems, Security and Sustainability, WS4 } 2020\end{array}$ & 143 & 0.1 & 0 \\
\hline $\begin{array}{c}\text { International Journal of Sustainable Development } \\
\text { and Planning }\end{array}$ & 142 & 0.5 & 1.4 \\
\hline $\begin{array}{c}\text { Proceedings of } 2020 \text { 13th International Conference } \\
\text { Management of Large-Scale System Development, } \\
\text { MLSD } 2020\end{array}$ & 140 & 0 & 0 \\
\hline Journal of Applied Engineering Science & 138 & 0.3 & 1.1 \\
\hline Environmental Innovation and Societal Transitions & 138 & 3.9 & 11.3 \\
\hline Nature Energy & 137 & 14.3 & 71.2 \\
\hline
\end{tabular}

Based on the SciVal database (www.scival.com, accessed on 7 April 2021); data source: Scopus (downloaded on 7 April 2021); copyright: Elsevier B.V.

\section{References}

1. Kostel, M.; Leus, D.; Cebotarenco, A.; Mokrushina, A. The sustainable development goals for Eastern partnership countries: Impact of institutions. Socioecon. Chall. 2017, 1, 79-90. [CrossRef]

2. Petrushenko, Y.; Vadym, A.; Vorontsova, A.; Ponomarenko, O. Sustainable development goals as a tool for strategic planning in communities: A bibliometric analysis of research. E3S Web Conf. 2020, 202, 03005. [CrossRef]

3. Chovancová, J.; Tej, J. Decoupling economic growth from greenhouse gas emissions: The case of the energy sector in V4 countries. Equilibrium. Q. J. Econ. Econ. Policy 2020, 15, 235-251. [CrossRef]

4. El Amri, A.; Oulfarsi, S.; Boutti, R.; Sahib Eddine, A.; Hmioui, A. Carbon financial markets underlying climate change mitigation, pricing and challenges: Technical analysis. Financ. Mark. Inst. Risks 2021, 5, 5-17. [CrossRef]

5. Mitic, P.; Kostic, A.; Petrovic, E.; Cvetanovic, S. The relationship between co2 emissions, industry, services and gross fixed capital formation in the Balkan countries. Eng. Econ. 2020, 31, 425-436. [CrossRef]

6. Samusevych, Y.; Vysochyna, A.; Vasylieva, T.; Lyeonov, S.; Pokhylko, S. Environmental, energy and economic security: Assessment and interaction. E3S Web Conf. 2021, 234, 00012. [CrossRef]

7. Destek, M.A.; Sinha, A. Renewable, non-renewable energy consumption, economic growth, trade openness and ecological footprint: Evidence from organisation for economic co-operation and development countries. J. Clean. Prod. 2020, $242,118537$. [CrossRef]

8. Didenko, I.; Volik, K.; Vasylieva, T.; Lyeonov, S.; Antoniuk, N. Migration, environment, and country safety: Analysis of touchpoints. E3S Web Conf. 2020, 202, 03028. [CrossRef]

9. Didenko, I.; Volik, K.; Vasylieva, T.; Lyeonov, S.; Antoniuk, N. Environmental migration and country security: Theoretical analysis and empirical research. E3S Web Conf. 2021, 234, 00010. [CrossRef] 
10. Lu, Z.; Gozgor, G.; Lau, C.K.M.; Paramati, S.R. The dynamic impacts of renewable energy and tourism investments on international tourism: Evidence from the G20 countries. J. Bus. Econ. Manag. 2019, 20, 1102-1120. [CrossRef]

11. Jonek-Kowalska, I. Coal mining in Central-East Europe in perspective of industrial risk. Oeconomia Copernic. 2017, 8, 131-143. [CrossRef]

12. Cebula, J.; Chygryn, O.; Chayen, S.V.; Pimonenko, T. Biogas as an alternative energy source in Ukraine and Israel: Current issues and benefits. Int. J. Environ. Technol. Manag. 2018, 21, 421-438. [CrossRef]

13. Jonek-Kowalska, I. Transformation of energy balances with dominant coal consumption in European economies and Turkey in the years 1990-2017. Oeconomia Copernic. 2019, 10, 627-647. [CrossRef]

14. Androniceanu, A.; Popescu, C.R. An inclusive model for an effective development of the renewable energies public sector. Adm. Public Manag. Rev. 2017, 28, 81-96.

15. Kasperowicz, R.; Pinczyński, M.; Khabdullin, A. Modeling the power of renewable energy sources in the context of classical electricity system transformation. J. Int. Stud. 2017, 10, 264-272. [CrossRef]

16. Kolcun, M.; Rusek, K.; Valentiny, T. Power plants of Poland and Slovakia in aspect of sustainable development. Pol. J. Manag. Stud. 2019, 20, 300-310. [CrossRef]

17. Kolosok, S.; Myroshnychenko, I.; Zakharkina, L. Open data in electrical energy balancing of Ukraine: Green deal and security aspects. CEUR Workshop Proc. 2020, 2732, 270-281. Available online: http:/ / ceur-ws.org/Vol-2732/20200270.pdf (accessed on 7 April 2021).

18. Androniceanu, A.; Georgescu, I.; Dobrin, C.; Dragulanescu, I.V. Multifactorial components analysis of the renewable energy sector in the OECD countries and managerial implications. Pol. J. Manag. Stud. 2020, 22, 36-49. [CrossRef]

19. Kolosok, S.; Myroshnychenko, I.; Mishenina, H.; Yarova, I. Renewable energy innovation in Europe: Energy efficiency analysis. E3S Web Conf. 2021, 234, 00021. [CrossRef]

20. Kolosok, S.; Pimonenko, T.; Yevdokymova, A.; Hajiyev, N.O.; Palienko, M.; Prasol, L. Energy efficiency policy: Impact of green innovations. Mark. Manag. Innov. 2020, 4, 50-60. [CrossRef]

21. Nitsenko, V.; Mardani, A.; Streimikis, J.; Shkrabak, I.; Klopov, I.; Novomlynets, O.; Podolska, O. Criteria for evaluation of efficiency of energy transformation based on renewable energy sources. Montenegrin J. Econ. 2018, 14, 237-247. [CrossRef]

22. Lyulyov, O.; Pimonenko, T.; Kwilinski, A.; Dzwigol, H.; Dzwigol-Barosz, M.; Pavlyk, V.; Barosz, P. The impact of the government policy on the energy efficient gap: The evidence from Ukraine. Energies 2021, 14, 373. [CrossRef]

23. Pavlyk, V. Assessment of green investment impact on the energy efficiency gap of the national economy. Financ. Mark. Inst. Risks 2020, 4, 117-123. [CrossRef]

24. Pavlyk, V. Institutional determinants of assessing energy efficiency gaps in the national economy. Socioecon. Chall. 2020, 4, 122-128. [CrossRef]

25. Tvaronavičienė, M.; Prakapienè, D.; Garškaitè-Milvydienè, K.; Prakapas, R.; Nawrot, Ł. Energy efficiency in the long run in the selected European countries. Econ. Sociol. 2018, 11, 245-254. [CrossRef] [PubMed]

26. Vakulenko, I.; Saher, L.; Syhyda, L.; Kolosok, S.; Yevdokymova, A. The first step in removing communication and organizational barriers to stakeholders' interaction in smart grids: A theoretical approach. E3S Web Conf. 2021, 234, 00020. [CrossRef]

27. Yan, Q.; Mikalauskiene, A.; Wan, Y.; Mikalauskas, I. Smart grids for renewable energy: Costs and benefits. Transform. Bus. Econ. 2017, 16, 430-439.

28. Kazemilari, M.; Mohamadi, A.; Mardani, A.; Streimikiene, D. Network topology of renewable energy sector in stock exchange. Montenegrin J. Econ. 2018, 14, 167-174. [CrossRef]

29. Rui, L.; Sineviciene, L.; Melnyk, L.; Kubatko, O.; Karintseva, O.; Lyulyov, O. Economic and environmental convergence of transformation economy: The case of China. Probl. Perspect. Manag. 2019, 17, 233-241. [CrossRef]

30. Rus, A.V.; Rovinaru, M.D.; Pirvu, M.; Bako, E.D.; Rovinaru, F.I. Renewable energy generation and consumption across 2030analysis and forecast of required growth in generation capacity. Transform. Bus. Econ. 2020, 19, 746-766.

31. Petrushenko, Y.; Kostyuchenko, N.; Smolennikov, D.; Vorontsova, A. Impact of the participatory financing of international development projects on social capital of the local communities. Probl. Perspect. Manag. 2017, 15, 183-192. [CrossRef]

32. Starchenko, L.; Lyeonov, S.; Vasylieva, T.; Pimonenko, T.; Lyulyov, O. Environmental management and green brand for sustainable entrepreneurship. E3S Web Conf. 2021, 234, 00015. [CrossRef]

33. Starchenko, L.V.; Samusevych, Y.V.; Demchuk, K. Social and eco-friendly entrepreneurship: The keys to sustainability. Bus. Ethics Leadersh. 2021, 5, 118-126. [CrossRef]

34. Yelnikova, Y.V.; Barhaq, A.R. Transparency of Responsible Investment Environment. Bus. Ethics Leadersh. 2020, 4, 68-75. [CrossRef]

35. Kaya Samut, P. Integrated FANP-f-MIGP model for supplier selection in the renewable energy sector. J. Bus. Econ. Manag. 2017, 18, 427-450. [CrossRef]

36. Klevas, V.; Bobinaite, V.; Marciukaitis, M.; Tarvydas, D. Microeconomic analysis for the formation of renewable energy support policy: The case of wind power sector in Lithuania. Eng. Econ. 2018, 29, 188-196. [CrossRef]

37. Sotnyk, I.; Shvets, I.; Momotiuk, L.; Chortok, Y. Management of renewable energy innovative development in Ukrainian households: Problems of financial support. Mark. Manag. Innov. 2018, 4, 150-160. [CrossRef]

38. Vasilieva, T.; Lieonov, S.; Makarenko, I.; Sirkovska, N. Sustainability information disclosure as an instrument of marketing communication with stakeholders: Markets, social and economic aspects. Mark. Manag. Innov. 2017, 4, 350-357. [CrossRef] 
39. Chortok, Y.; Yevdokymova, A.; Serpeninova, Y. Formation of the mechanism of corporate social and environmental responsibility of the trading company. J. Environ. Manag. Tour. 2018, 9, 1011-1018. [CrossRef]

40. Kasych, A.; Vochozka, M. Theoretical and methodical principles of managing enterprise sustainable development. Mark. Manag. Innov. 2017, 2, 298-305. [CrossRef]

41. Liuta, O.; Pihul, N.; Kubakh, T. Financial capacity of local budget as a basis for sustainable functioning of a territory. Econ. Ann. XXI 2015, 1-2, 78-81. Available online: https://www.scopus.com/record/display.uri?eid=2-s2.0-84939243561\&origin=resultslist (accessed on 7 April 2021).

42. Taliento, M.; Netti, A. Corporate Social/Environmental Responsibility and Value Creation: Reflections on a Modern Business Management Paradigm. Bus. Ethics Leadersh. 2020, 4, 123-131. [CrossRef]

43. Dkhili, H. Environmental performance and institutions quality: Evidence from developed and developing countries. Mark. Manag. Innov. 2018, 3, 333-344. [CrossRef]

44. Vasylieva, T.; Machová, V.; Vysochyna, A.; Podgórska, J.; Samusevych, Y. Setting up architecture for environmental tax system under certain socioeconomic conditions. J. Int. Stud. 2020, 13, 273-285. [CrossRef]

45. Vysochyna, A.; Samusevych, Y.; Starchenko, L. Convergence trends of environmental taxation in european countries. E3S Web Conf. 2020, 202, 03031. [CrossRef]

46. Zhulavskyi, A.Y.; Smolennikov, D.O.; Kostyuchenko, N.M. Social and environmental responsibility strategies of business. Nauk. Visnyk Natsionalnoho Hirnychoho Universytetu 2017, 3, 134-139. Available online: http://nv.nmu.org.ua/index.php/en/archive/ on-the-issues /1438-2017-eng/contents-3-2017/ economy-and-management/4013-social-and-environmental-responsibilitystrategies-of-business (accessed on 7 April 2021).

47. Vysochyna, A.; Stoyanets, N.; Mentel, G.; Olejarz, T. Environmental determinants of a country's food security in short-term and long-term perspectives. Sustainability 2020, 12, 4090. [CrossRef]

48. Yarovenko, H. Evaluating the threat to national information security. Probl. Perspect. Manag. 2020, 18, 195-210. [CrossRef]

49. Ziabina, Y.A.; Pimonenko, T.V.; Starchenko, L.V. Energy efficiency of national economy: Social, economic and ecological indicators. Socioecon. Chall. 2020, 4, 160-174. [CrossRef]

50. Matvieieva, Y.; Myroshnychenko, I.; Valenkevych, L. Optimization model of the socio-ecological-economic development of the administrative territory. J. Environ. Manag. Tour. 2019, 10, 1874-1899. [CrossRef]

51. Vasilyeva, T.; Bilan, S.; Bagmet, K.; Seliga, R. Institutional development gap in the social sector: Crosscountry analysis. Econ. Sociol. 2020, 13, 271-294. [CrossRef]

52. Vasilyeva, T.; Kuzmenko, O.; Bozhenko, V.; Kolotilina, O. Assessment of the dynamics of bifurcation transformations in the economy. CEUR Workshop Proc. 2019, 2422, 134-146. Available online: https:/ / www.scopus.com/record/display.uri?eid=2-s2.0 -85071124329\&origin=resultslist (accessed on 7 April 2021).

53. Vorontsova, A.; Vasylieva, T.; Bilan, Y.; Ostasz, G.; Mayboroda, T. The influence of state regulation of education for achieving the sustainable development goals: Case study of central and eastern European countries. Adm. Public Manag. Rev. 2020, 2020, 6-26. [CrossRef]

54. Vorontsova, A.; Shvindina, H.; Mayboroda, T.; Mishenina, H.; Heiets, I. The impact of state regulation in a sphere of education on sustainable development of national economy. Probl. Perspect. Manag. 2020, 18, 275-288. [CrossRef]

55. Green, M.A.; Dunlop, E.D.; Hohl-Ebinger, J.; Yoshita, M.; Kopidakis, N.; Ho-Baillie, A.W.Y. Solar cell efficiency tables (version 55). Prog. Photovolt. Res. Appl. 2020, 28, 3-15. [CrossRef]

56. Khenkin, M.V.; Katz, E.A.; Abate, A.; Bardizza, G.; Berry, J.J.; Brabec, C.; Lira-Cantu, M. Consensus statement for stability assessment and reporting for perovskite photovoltaics based on ISOS procedures. Nat. Energy 2020, 5, 35-49. [CrossRef]

57. Keliuotytè-Staniulènienè, G.; Daunaravičiūtè, K. The global green bond market in the face of the COVID-19 pandemic. Financ. Mark. Inst. Risks 2021, 5, 50-60. [CrossRef]

58. Klemeš, J.J.; Fan, Y.V.; Tan, R.R.; Jiang, P. Minimising the present and future plastic waste, energy and environmental footprints related to COVID-19. Renew. Sustain. Energy Rev. 2020, 127, 109883. [CrossRef] [PubMed]

59. Myroshnychenko, I.; Makarenko, I.; Smolennikov, D.; Buriak, A. The approach to managing corporate social and environmental responsibility in manufacturing. TEM J. 2019, 8, 740-748. [CrossRef]

60. Kokol, P.; Završnik, J.; Turčin, M.; Vošner, H.B. Enhancing the role of academic librarians in conducting scoping reviews. Libr. Philos. Pract. 2020, 2020, 1-17.

61. Schultz, A.; Goertzen, L.; Rothney, J.; Wener, P.; Enns, J.; Halas, G.; Katz, A. A scoping approach to systematically review published reviews: Adaptations and recommendations. Res. Synth. Methods 2018, 9, 116-123. [CrossRef]

62. Adhikari, G.C.; Thapa, S.; Zhu, H.; Zhu, P. UV Resin Enhanced Stability of Metal Halide Perovskite Nanocrystals for White Light-Emitting Diodes. ACS Appl. Electron. Mater. 2020, 2, 35-40. [CrossRef]

63. Adhikari, G.C.; Thapa, S.; Yue, Y.; Zhu, H.; Zhu, P. Near Unity PLQY and High Stability of Barium Thiocyanate Based All-Inorganic Perovskites and Their Applications in White Light-Emitting Diodes. Photonics 2021, 8, 209. [CrossRef]

64. Vedik, B.; Kumar, R.; Deshmukh, R.; Verma, S.; Shiva, C.K. Renewable Energy-Based Load Frequency Stabilization of Interconnected Power Systems Using Quasi-Oppositional Dragonfly Algorithm. J. Control Autom. Electr. Syst. 2021, 32, 227-243. [CrossRef] 
65. Ayadi, F.; Colak, I.; Garip, I.; Bulbul, H.I. Impacts of Renewable Energy Resources in Smart Grid. In Proceedings of the 2020 8th International Conference on Smart Grid (ICSMARTGRID), Kuching, Malaysia, 4-7 October 2020; IEEE: Piscataway, NJ, USA, 2020; pp. 183-188.

66. Kamble, S.S.; Gunasekaran, A.; Sharma, R. Modeling the blockchain enabled traceability in agriculture supply chain. Int. J. Inf. Manag. 2020, 52, 101967. [CrossRef]

67. Wong, L.W.; Leong, L.Y.; Hew, J.J.; Tan, G.W.H.; Ooi, K.B. Time to seize the digital evolution: Adoption of blockchain in operations and supply chain management among Malaysian SMEs. Int. J. Inf. Manag. 2020, 52, 101997. [CrossRef]

68. Sharma, R.; Kamble, S.S.; Gunasekaran, A.; Kumar, V.; Kumar, A. A systematic literature review on machine learning applications for sustainable agriculture supply chain performance. Comput. Oper. Res. 2020, 119, 104926. [CrossRef]

69. Cui, Y.; Kara, S.; Chan, K.C. Manufacturing big data ecosystem: A systematic literature review. Robot. Comput. Integr. Manuf. 2020, 62, 101861. [CrossRef]

70. Du, Y.; Zhou, S.; Jing, X.; Peng, Y.; Wu, H.; Kwok, N. Damage detection techniques for wind turbine blades: A review. Mech. Syst. Signal Process. 2020, 141, 106445. [CrossRef]

71. Alonso, R.S.; Sittón-Candanedo, I.; García, Ó.; Prieto, J.; Rodríguez-González, S. An intelligent Edge-IoT platform for monitoring livestock and crops in a dairy farming scenario. Ad Hoc Netw. 2020, 98, 102047. [CrossRef]

72. Squazzoni, F.; Polhill, J.G.; Edmonds, B.; Ahrweiler, P.; Antosz, P.; Scholz, G.; Chappin, É.; Borit, M.; Verhagen, H.; Giardini, F.; et al. Computational models that matter during a global pandemic outbreak: A call to action. J. Artif. Soc. Soc. Simul. 2020, 23, 10. Available online: https:/ /www.jasss.org/23/2/10.html (accessed on 7 April 2021). [CrossRef]

73. Barteit, S.; Guzek, D.; Jahn, A.; Bärnighausen, T.; Jorge, M.M.; Neuhann, F. Evaluation of e-learning for medical education in low-and middle-income countries: A systematic review. Comput. Educ. 2020, 145, 103726. [CrossRef] [PubMed]

74. Kadar, T.; Kadar, M. Sustainability Is Not Enough: Towards AI Supported Regenerative Design. In Proceedings of the 2020 IEEE International Conference on Engineering, Technology and Innovation (ICE/ITMC), Cardiff, UK, 15-17 June 2020; IEEE: Piscataway, NJ, USA, 2020; pp. 1-6.

75. Piovesan, N.; López-Pérez, D.; Miozzo, M.; Dini, P. Joint Load Control and Energy Sharing for Renewable Powered Small Base Stations: A Machine Learning Approach. IEEE Trans. Green Commun. Netw. 2020, 5, 512-525. [CrossRef]

76. $\mathrm{Wu}, \mathrm{Q}$.; Zhang, R. Towards smart and reconfigurable environment: Intelligent reflecting surface aided wireless network. IEEE Commun. Mag. 2020, 58, 106-112. [CrossRef]

77. Mistry, I.; Tanwar, S.; Tyagi, S.; Kumar, N. Blockchain for 5G-enabled IoT for industrial automation: A systematic review, solutions, and challenges. Mech. Syst. Signal Process. 2020, 135, 106382. [CrossRef]

78. Shafique, K.; Khawaja, B.A.; Sabir, F.; Qazi, S.; Mustaqim, M. Internet of things (IoT) for next-generation smart systems: A review of current challenges, future trends and prospects for emerging 5G-IoT scenarios. IEEE Access 2020, 8, 23022-23040. [CrossRef]

79. Narayanan, S.; Chaniotakis, E.; Antoniou, C. Shared autonomous vehicle services: A comprehensive review. Transp. Res. Part C Emerg. Technol. 2020, 111, 255-293. [CrossRef]

80. Zhang, J.; Xie, Z.; Sun, J.; Zou, X.; Wang, J. A cascaded R-CNN with multiscale attention and imbalanced samples for traffic sign detection. IEEE Access 2020, 8, 29742-29754. [CrossRef]

81. Tamiminia, H.; Salehi, B.; Mahdianpari, M.; Quackenbush, L.; Adeli, S.; Brisco, B. Google Earth Engine for geo-big data applications: A meta-analysis and systematic review. ISPRS J. Photogramm. Remote Sens. 2020, 164, 152-170. [CrossRef]

82. Rasouli, A.; Tsotsos, J.K. Autonomous vehicles that interact with pedestrians: A survey of theory and practice. IEEE Trans. Intell. Transp. Syst. 2020, 21, 900-918. [CrossRef]

83. Gassar, A.A.A.; Cha, S.H. Energy prediction techniques for large-scale buildings towards a sustainable built environment: A review. Energy Build. 2020, 224, 110238. [CrossRef]

84. Kazerani, M.; Tehrani, K. Grid of Hybrid AC/DC Microgrids: A New Paradigm for Smart City of Tomorrow. In Proceedings of the 2020 IEEE 15th International Conference of System of Systems Engineering (SoSE), Budapest, Hungary, 2-4 June 2020; IEEE: Piscataway, NJ, USA, 2020; pp. 175-180.

85. Kaur, K.; Garg, S.; Kumar, N.; Aujla, G.S.; Choo, K.K.R.; Obaidat, M.S. An adaptive grid frequency support mechanism for energy management in cloud data centers. IEEE Syst. J. 2020, 14, 1195-1205. [CrossRef] 